\title{
PENAMBANGAN TIMAH INKONVENSIONAL: DAMPAKNYA TERHADAP KERUSAKKAN BIODIVERSITAS PERAIRAN UMUM DI PULAU BANGKA
}

\author{
Eko Prianto dan Husnah \\ Peneliti pada Balai Riset Perikanan Perairan Umum, Mariana-Palembang \\ Teregistrasi I tanggal: 28 April 2009; Diterima setelah perbaikan tanggal: 3 Juni 2009; \\ Disetujui terbit tanggal: 15 Juni 2009
}

\begin{abstract}
ABSTRAK
Penambangan timah inkonvensional di Pulau Bangka telah berlangsung sejak tahun 2000. Kegiatan ini dilakukan oleh masyarakat atau pengusaha tanpa mendapat izin dari pemerintah. Pada tahun 2002 jumlah timah inkonvensional sekitar 6.000 unit yang tersebar di seluruh Pulau Bangka. Kegiatan ini telah memberikan dampak yang sangat besar terhadap ekosistem perairan dan masyarakat sekitarnya. Aktivitas ini telah memberikan dampak yang sangat buruk terhadap ekosistem perairan seperti 1) sedimentasi dan perubahan bentang alam kawasan pesisir, 2) meningkatnya kesuburan perairan, 3) peningkatan kekeruhan perairan, 4) kerusakkan ekosistem dan musnahnya biota perairan, dan 5) pencemaran logam berat. Kasus penambangan timah inkonvensional ini dikhawatirkan dapat menjadi fenomena gunung es yang suatu saat dapat menjadi konflik horisontal antar sesama masyarakat. Untuk menghindari hal ini pemerintah perlu menata ulang sistem pengelolaan dan perizinan pada pihak yang melakukan penambangan timah di Pulau Bangka.
\end{abstract}

KATAKUNCI: penambangan timah, Pulau Bangka, inkonvensional, logam berat

\section{PENDAHULUAN}

Pulau Bangka memiliki karakteristik menarik dibandingkan dengan wilayah lainnya di Indonesia, terutama dilihat dari potensi sumber daya alam yang unik seperti lada, pasir kuarsa, kaolin, dan timah. Ketersediaan sumber daya alam tersebut sangat ditentukan oleh kondisi geologi wilayah, terutama yang berkaitan dengan struktur, tektonik, dan litologi yang membentuknya. Kegiatan penambangan timah merupakan mata pencarian utama di Pulau Bangka. Sumber daya timah merupakan komoditi andalan Propinsi Bangka-Belitung yang telah dimulai sejak abad ke-17 oleh Pemerintah Hindia Belanda dan secara resmi dikelola pemerintah Indonesia pada tahun 1952. Sejak tahun 1976 kegiatan penambangan timah ditangani oleh PT. Tambang Timah sampai sekarang (PT. Tambang Timah, 2000).

Berbagai perubahan dalam struktur politik nasional (termasuk desentralisasi kekuasaan pemerintah) dan dalam struktur dan kinerja perekonomian nasional, membawa dampak yang sangat dramatis dalam pengelolaan tambang timah di daerah ini. Sejak tahun 2000, banyak ditemukan penambangan timah yang dilakukan oleh masyarakat setempat secara inkonvensional yang tidak mempunyai surat kuasa dari pemerintah setempat. Pada dasarnya pemerintah daerah dan pemerintah pusat telah menyikapi perkembangan ini dengan menerbitkan berbagai peraturan perundang-undangan untuk mengendalikannnya. Namun dalam perkembangannya, peraturan perundang-undangan tersebut sampai saat ini belum mampu mengendalikan masalah ini. Bahkan, hasil pengamatan lapangan menunjukkan penambangan ilegal ini cenderung semakin berkembang liar. Diperkirakan pada tahun 2002 jumlah tambang inkonvensional sekitar 6.000 unit yang tersebar di Pulau Bangka. (PPLH IPB dan Bapedalda Kabupaten Bangka, 2002).

Aktivitas penambangan yang sangat tinggi yang dilakukan oleh masyarakat ternyata telah menimbulkan bermacam-macam efek yang buruk bagi kehidupan manusia dan tatanan lingkungan hidup. Aktivitas yang pada prinsipnya merupakan usaha manusia untuk dapat hidup dengan layak dan berketurunan dengan baik, telah merangsang manusia untuk melakukan tindakan-tindakan yang menyalahi kaidah-kaidah yang ada dalam tatanan lingkungan hidupnya. Akibatnya terjadi pergeseran keseimbangan dalam tatanan lingkungan dari bentuk asal ke bentuk baru yang cenderung lebih buruk. Namun yang paling utama dari sekian banyak penyebab tercemarnya suatu tatanan lingkungan adalah limbah baik padat maupun cair.

Meningkatnya kegiatan tersebut secara dramatis telah menimbulkan berbagai permasalahan serius di Pulau Bangka. Selain kerusakkan sumber daya alam dan lingkungan hidup yang serius serta implikasinya terhadap keberlanjutan perekonomian Pulau Bangka di masa depan, hal lain yang perlu dipertanyakan adalah sejauh mana hasil kegiatan tambang inkonvensional sekarang ini dinikmati oleh masyarakat bawah, khususnya para buruh tambang 
yang terlibat. Kesulitan ekonomi yang dialami masyarakat bawah sebagai akibat krisis ekonomi nasional selama 5 tahun terakhir telah dibuat menjadi salah satu argumentasi penting untuk mentolerir kegiatan tambang inkonvensional sekarang ini, meskipun kegiatan tersebut bersifat ilegal dan kegiatan produksinya tidak mengikuti prosedur baku penambangan timah, sehingga menimbulkan kerusakkan pada lingkungan dan sumber daya alam, khsususnya perairan umum di Pulau Bangka.

\section{TIPOLOGI PERAIRAN UMUM PULAU BANGKA}

Pulau Bangka terletak di sebelah pesisir timur Sumatera Selatan, berbatasan dengan Laut Cina Selatan di sebelah utara, Pulau Belitung di timur dan Laut Jawa di sebelah selatan yaitu $1^{\circ} 20^{\prime}-3^{\circ} 7^{\prime}$ LS dan $105^{\circ}-107^{\circ} \mathrm{BT}$ memanjang dari barat laut ke tenggara sepanjang $\pm 180 \mathrm{~km}$. Dilihat dari kondisi topografinya, Pulau Bangka memiliki kontur wilayah yang berbukitbukit dan terdiri atas rawa-rawa, daratan rendah, bukitbukit, dan puncak bukit terdapat hutan lebat, sedangkan pada daerah rawa terdapat hutan bakau. Rawa daratan Pulau Bangka tidak begitu berbeda dengan rawa di Pulau Sumatera, sedangkan keistimewaan pantainya dibandingkan dengan daerah lain adalah pantainya yang landai berpasir putih dengan dihiasi hamparan batu granit (http:// wapedia.mobi/id/Suku_Bangka. 2007).

Letak rawanya juga terpisah-pisah yaitu di daerah Belo Laut, Sungai Selan, dan Payung, sehingga tidak selalu berada di sepanjang pantai (Balai Penelitian dan Pengembangan Pertanian, 1996). Sungaisungainya sebagian besar dimanfaatkan masyarakat sebagai jalur transportasi dan pemenuhan kebutuhan rumah tangga, serta industri. Banyak hasil publikasi yang mengatakan bahwa beberapa jenis ikan yang hidup di perairan umum Pulau Bangka merupakan ikan yang endemik dan beberapa jenis sudah termasuk dalam redlist IUCN. Jenis-jenis ikan tersebut Betta burdigala dan Betta chloropharynx (IUCN, 2001 dalam Wargasasmita, 2002).

\section{DAMPAK AKTIVITAS PENAMBANGAN}

\section{Sedimetasi dan Perubahan Bentang Alam Kawasan Pesisir}

Hampir semua sungai di Pulau Bangka beralih fungsi sebagai penampung limbah yang berasal dari penambangan timah. Di daerah muara, kemiringan dasar sungai menjadi relatif kecil sebagai akibat dari endapan pasir dan material-material yang lain, sehingga kapasitas tampungan sungainya menjadi berkurang. Sedimentasi yang terjadi di suatu perairan dapat berpengaruh antara lain pada pendangkalan dan perubahan bentang alam dasar laut, kesuburan perairan, dan hilangnya keanekaragaman hayati perairan.

Padatan tersuspensi dan butiran-butiran pasir hasil penyaringan akan dibuang langsung ke perairan tanpa diendapkan terlebih dahulu pada kolam penampungan atau tendon. Air bekas cucian menjadi keruh (putih susu) dengan kandungan padatan tersuspensi yang sangat tinggi. Air buangan akan terbawa arus sungai, dan selanjutnya sebagian partikel-partikel tanah akan mengendap di dasar sungai. Proses ini secara berkelanjutan akan menyebabkan terjadinya pendangkalan sungai dan menutupi permukaan dasar sungai. Penutupan permukaan tanah ini dalam jangka panjang dapat menyebabkan kematian terhadap organisme bentos yang dalam sistem ekologi berfungsi sebagai dekomposer.

Sedimentasi yang tinggi di wilayah pesisir telah menyebabkan terjadinya perubahan bentang alam di daerah pantai. Hal ini disebabkan, adanya penambangan timah di hulu sungai dan di sepanjang pantai Pulau Bangka. Tingginya aktivitas penambangan di sepanjang pantai telah menyebabkan pada beberapa bagian terjadi proses pendalaman akibat pengambilan tanah dasar laut dan pada bagian lain terjadi penumpukkan butiran tanah.

\section{Kesuburan Perairan}

Ketika penambangan timah akan dimulai lapisan tanah bagian permukaan yang kaya akan humus diangkat untuk memudahkan dalam penggalian. Setelah penggalian mencapai kedalaman $\pm 2-3 \mathrm{~m}$, selanjutnya dilakukan penggalian yang dilakukan dengan menggunakan mesin atau secara manual. Tanah yang diambil selanjutnya dilakukan proses pencucian dan penyaringan agar timah dapat terpisah dari tanah. Bahan organik yang berasal dari pencucian ini selanjutnya akan terbawa oleh air menuju sungaisungai di sekitar lokasi penambangan.

Masuknya bahan organik ke perairan sungai dalam jumlah yang berlebih dapat menyebabkan kesuburan perairan menjadi tinggi, sehingga akan menstimulir blooming (ledakkan) populasi fitoplankton dan mikroba air yang bersifat patogen. Limbah zat hara dan organik baik dalam bentuk terlarut maupun partikel, berasal dari pakan yang tidak dimakan dan ekskresi ikan, yang pada umumnya dikarakterisasi oleh peningkatan total padatan tersuspensi (TSS), biological oxigen deman $\left(B O D_{5}\right)$, chemical oxigen deman $(C O D)$, dan kandungan $\mathrm{C}, \mathrm{N}$, dan $\mathrm{P}$. Secara potensial, penyebaran dampak buangan limbah yang kaya zat hara dan 
bahan organik tersebut dapat meningkatkan sedimentasi, siltasi, hipoksia, hipernutrifikasi, dan perubahan produktivitas serta struktur komunitas bentik. Fenomena-fenomena tersebut menunjukkan bahwa pencemaran yang terjadi di perairan Bangka semakin mengkhawatirkan karena dapat mengancam kelestarian fungsi sungai dan rawa.

\section{Peningkatan Kekeruhan Perairan}

Kekeruhan disebabkan adanya bahan-bahan tersuspensi seperti tanah liat, pasir, bahan organik, bakteri, plankton, dan jasad-jasad renik lainnya. Kekeruhan menggambarkan sifat optik suatu perairan di mana cahaya dibaurkan atau diserap karena adanya bahan-bahan tersuspensi tersebut. Kekeruhan secara tidak langsung mempengaruhi produktivitas, perairan karena kekeruhan yang tinggi akan mempengaruhi penetrasi cahaya kedalam perairan dan akan menghambat proses fotosintesis. Selain itu dampak kekeruhan dapat menyebabkan kematian ikan akibat rusaknya alat-alat pernapasan serta kerusakkan daerah pemijahan dan pengasuhan bagi organisme air terutama ikan.

Kekeruhan perairan terutama sungai di Pulau Bangka secara umum, disebabkan aktivitas timah inkonvensional di sekitar pulau. Kekeruhan ini merupakan dampak yang paling nyata dari aktivitas penambangan yang disebabkan partikel-partikel tanah terlarut atau tersuspensi di dalam perairan. Hasil dari pengukuran TSS pada beberapa sungai yang terkena dampak penambangan timah inkonvensional disajikan pada Tabel 1.

Berdasarkan pada Peraturan Gubernur Sumatera Selatan No.16 Tahun 2005 tentang kandungan residu tersuspensi untuk kegiatan budi daya perikanan 400 $\mathrm{mg} / \mathrm{L}$. Berdasarkan pada data di atas maka nilai TSS di beberapa sungai di Pulau Bangka telah melebihi baku mutu air sungai. Suspensi partikel dalam air mempunyai pengaruh yang sangat bervariasi terhadap ikan. Pengaruh yang paling besar terjadi bila air mengandung partikel-partikel padat sampai $4 \%$ volume (Siagian et al., 1996). Pengaruh yang paling besar adalah terjadinya pengaruh mekanis dari partikel-

Tabel 1. Hasil pengukuran nilai TSS

di beberapa sungai di Pulau Bangka

\begin{tabular}{clc}
\hline No. & Nama sungai & Nilai TSS $(\mathbf{m g} / \mathbf{L})$ \\
\hline 1. & Penyak & $3.300-8.000$ \\
2. & Jeruk & $6.500-15.700$ \\
3. & Mancung & $1.000-1.200$ \\
4. & Kepoh & $2.500-5.300$ \\
\hline
\end{tabular}

partikel mineral pada berbagai ukuran mulai dari beberapa mikron sampai 2-3 cm yang terbawa dalam air. Adanya bahan-bahan tersuspensi dalam air juga menghambat respirasi ikan. Kematian dapat terjadi karena sufokasi (kesulitan bernafas) akibat insangnya tersumbat oleh partikel-partikel tersuspensi tersebut.

\section{Kerusakkan Ekosistem dan Musnahnya Biota Perairan}

Dampak penimbunan oleh sedimen (sedimentasi) yang terjadi di perairan baik secara langsung maupun tidak langsung berhubungan dengan keberadaaan keanekaragaman hayati. Penimbunan dasar perairan oleh sedimen dapat merusak dan memusnahkan komunitas hewan bentik dan lokasi pemijahan biota perairan lainnya. Partikel tanah yang tersuspensi akan menutupi habitat (tanaman air, permukaan tanah) dan telur-telur seluruh biota perairan, sehingga telur tidak dapat berkembang dengan baik. Dampak ini lambat laun akan menyebabkan penurunan populasi secara masal yang akhirnya dalam jangka panjang dapat menurunkan keanekaragaman hayati perairan.

Keanekaragaman hayati perairan umum merupakan sumber lukang genetik yang penting untuk dimanfaatkan bagi kehidupan manusia yakni sumber pendapatan dan kehidupan masyarakat. Oleh karena itu keberadaannya sangat rawan dari kepunahan bila tidak diimbangi dengan upaya pelestarian dan pengelolaan yang berkelanjutan. Sejalan dengan perkembangan pembangunan dan pertumbuhan ekonomi masyarakat, berbagai dampaknya terhadap kelestarian keanekaragaman hayati dan lingkungannya sering dijumpai.

\section{Pencemaran Logam Berat}

Pencemaran atau polusi adalah suatu kondisi yang telah berubah dari bentuk asal (baik) menjadi keadaan yang lebih buruk. Pergesaran bentuk tatanan dari kondisi asal pada kondisi yang buruk ini dapat terjadi sebagai masukkan dari bahan-bahan pencemar atau polutan. Bahan polutan tersebut pada umumnya mempunyai sifat racun (toksik) yang berbahaya bagi kelangsungan hidup organisme. Toksisitas atau daya racun dari polutan itu yang kemudian menjadi pemicu terjadinya pencemaran (Palar, 2004).

Perairan umum di Pulau Bangka sangat rentan tercemar timah hitam yang merupakan salah satu jenis logam berat yang sangat berbahaya. Jika dilihat dari proses pengambilan, pencucian, dan pengolahannya maka pencemaran logam berat sangat 

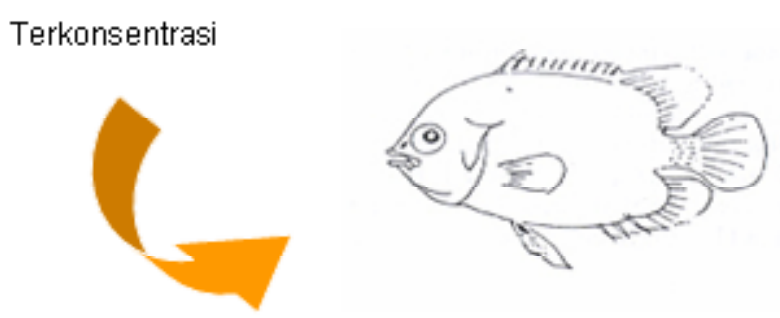

Metaliothionein

1. Mengikat

2 Menyimpan

3 Menyekap

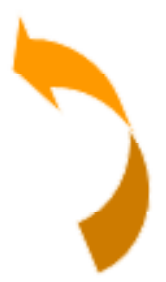

Terakumulasi

Gambar 1. Proses akumulasi logam berat pada ikan (Sumber: Lasut, 2001)

mungkin terjadi. Timah hitam yang terlarut dalam badan perairan pada konsentrasi tertentu akan merubah fungsi menjadi sumber racun bagi kehidupan perairan. Meskipun daya racun yang ditimbulkan oleh suatu jenis logam berat terhadap biota perairan tidak sama, namun kehancuran dari satu kelompok mengakibatkan terputusnya mata rantai kehidupan lainnya. Selanjutnya, keadaan tersebut tentu dapat menghancurkan satu tatanan eksositem parairan.

Keberadaan timah hitam dalam badan perairan dapat berasal dari sumber-sumber alamiah, namun pada umumnya berasal dari aktivitas manusia. Sumber-sumber timah hitam secara alamiah yang masuk ke dalam badan perairan dapat berupa pengikisan dari batu mineral yang banyak di sekitar perairan. Pada umumnya logam-logam termasuk timah hitam yang terdapat dalam tanah dan perairan dalam bentuk persenyawaan seperti senyawa hidroksida, senyawa oksida, senyawa karbonat, dan senyawa sulfida. Senyawa-senyawa tersebut sangat mudah larut dalam air. Namun demikian, pada badan perairan yang mempunyai derajat keasaman $(\mathrm{pH})$ mendekati normal atau pada kisaran $\mathrm{pH}$ 7-8, kelarutan dari senyawa-senyawa ini cenderung lebih stabil. Kenaikan $\mathrm{pH}$ pada badan perairan akan diikuti dengan semakin kecilnya kelarutan dari senyawa-senyawa logam tersebut (Palar, 2004).

Proses fisiologi yang terjadi pada setiap biota turut mempengaruhi tingkat logam berat yang menumpuk (akumulasi) dalam tubuh biota perairan. Variasi jumlah logam berat yang terkandung dalam tubuh ikan tergantung pada daya racun yang ditimbulkan oleh logam berat. Di samping itu, proses fisiologi ini turut mempengaruhi peningkatan kandungan logam berat dalam badan perairan. Ada biota-biota tertentu yang mempunyai kemampuan untuk mentoleransi logam berat tertentu sampai pada konsentrasi tinggi dan ada yang memiliki kemampuan untuk menetralisir daya racun dari logam berat pada konsentrasi rendah.
Pada Gambar 1 dapat dilihat proses akumulasi logam berat pada ikan, di mana logam berat yang masuk dalam perairan secara langsung akan mencemari perairan sehingga melalui sistem makanan akan menyebabkan plankton dalam perairan akan mengandung logam berat di tubuhnya. Melalui rantai makanan, ikan akan memakan plankton sehingga terjadi pengikatan, penyimpanan, dan penyekapan logam berat di dalam tubuh ikan. Selanjutnya proses ini berlanjut secara terus-menerus dan mengakibatkan terakumulasi logam berat dalam tubuh ikan.

\section{DAMPAK PENCEMARAN LOGAM BERAT}

Timah hitam dan persenyawaannya dapat berada di dalam badan perairan secara alamiah dan sebagai dampak dari aktivitas manusia. Secara alamiah, timah hitam dapat masuk ke badan perairan melalui pengkristalan timah hitam di udara dengan bantuan air hujan, dan proses korofikasi dari batuan mineral. Timah hitam yang masuk ke dalam badan perairan sebagai dampak dari aktivitas kehidupan manusia dapat terwujud dalam bermacam bentuk. Di antaranya air yang berasal dari buangan (limbah) industri yang berkaitan dengan timah hitam, dan air buangan dari penambangan biji timah hitam. Buangan tersebut akan jatuh pada jalur-jalur perairan seperti anak-anak sungai, kemudian akan dibawa terus menuju lautan. Pada umumnya jalur buangan dari bahan sisa industri yang menggunakan timah hitam akan merusak tata lingkungan perairan yang dimasukinya (menjadi sungai dan alurnya tercemar) (Palar, 2004).

Badan perairan yang telah tercemar, jumlah senyawa atau ion-ion timah hitam $(\mathrm{Pb})$, yang melebihi konsentrasi yang semestinya, dapat mengakibatkan kematian bagi biota perairan tersebut. Menurut Murphy (1979) dalam Palar (2004) biota-biota perairan seperti krustacea akan mengalami kematian setelah $245 \mathrm{jam}$, bila badan perairan tempat biota ini hidup terlarut $\mathrm{Pb}$ 
Tabel 2.

Karakteristik konsentrasi parameter fisika kimia limbah cair pertambangan timah Pulau Bangka

\begin{tabular}{lccc}
\multicolumn{1}{c}{ Parameter (satuan) } & Limbah cair I & Limbah cair II & Limbah cair III \\
\hline Suhu $\left({ }^{\circ} \mathrm{C}\right)$ & 29,8 & 28,9 & 30,8 \\
Kekeruhan (NTU) & 7.770 & 913 & 696,8 \\
TSS (mg/L) & 14.792 & 2.374 & 582 \\
pH & 4,52 & 4,44 & 4,62 \\
$\mathrm{BOD}(\mathrm{mg} / \mathrm{L})$ & 4,26 & 7,30 & (tidak ada data) \\
$\mathrm{COD}(\mathrm{mg} / \mathrm{L})$ & 9,84 & 17,05 & 93,77 \\
$\mathrm{~N}-\mathrm{organik}(\mathrm{mg} / \mathrm{L})$ & 0,016 & 0,082 & 0 \\
$\mathrm{P}(\mathrm{mg} / \mathrm{L})$ & 0,385 & 0,305 & 0,046 \\
Sulfida $(\mathrm{mg} / \mathrm{L})$ & 1,45 & 1,86 & 0,90 \\
$\mathrm{Cd}(\mathrm{mg} / \mathrm{L})$ & 0,014 & 0,015 & 0,028 \\
$\mathrm{Cr}(\mathrm{mg} / \mathrm{L})$ & 0,042 & 0,032 & 0,045 \\
$\mathrm{Hg}(\mathrm{mg} / \mathrm{L})$ & $\mathrm{Ttd}$ & $\mathrm{Ttd}$ & $\mathrm{Ttd}$ \\
$\mathrm{Cu}(\mathrm{mg} / \mathrm{L})$ & 0,025 & 0,029 & 0,016 \\
$\mathrm{~Pb}(\mathrm{mg} / \mathrm{L})$ & 0,087 & 0,095 & 0,052 \\
$\mathrm{Sn}(\mathrm{mg} / \mathrm{L})$ & 0,64 & 0,56 & 0,72 \\
Fenol $(\mathrm{mg} / \mathrm{L})$ & ttd & ttd & 0,035 \\
\hline
\end{tabular}

Keterangan: limbah cair I: timah inkonvensional di daerah aliran Sungai Kepoh; limbah cair II: timah inkonvensional di daerah Pemali; limbah cair III: timah inkonvensional secara manual di daerah Rias

Sumber: Laboratorium Lingkungan PPLH-IPB (2002) dalam PPLH IPB dan Bapedalda Kabupaten Bangka (2002)

dengan konsentrasi 2,75-49,00 mg/L. Sedangkan biota perairan lainnya, yang dikelompokkan dalam golongan insekta akan mengalami kematian dalam rentang waktu yang lebih panjang, yaitu antara 168-336 jam, bila pada badan perairan tempat hidupnya terlarut 3,5$64,0 \mathrm{mg} \mathrm{Pb} / \mathrm{L}$.

Konsentrasi logam berat pada perairan di wilayah penambangan ilegal di Pulau Bangka walaupun dalam konsentrasi yang kecil, namun dampak yang ditimbulkannya terhadap organisme akuatik dalam jangka panjang perlu diperhatikan, mengingat sifat logam berat tersebut yang akan terakumulasi dalam organ organisme akuatik seperti ikan, krustacea, dan moluska. Tabel 2 Pada beberapa lokasi penambangan timah di Pulau Bangka secara umum kualitas perairan tidak mengalami perubahan secara drastis namun nilai kekeruhan dan TSS sangat tinggi sedangkan nilai logam berat dalam jumlah yang kecil. Walaupun demikian perlu diwaspadai ke depannya dampak dari aktivitas ini terutama sifat logam berat yang dapat terakumulasi dalam biota perairan.

\section{Upaya Pengelolaan}

Sejak dimulainya penambangan timah ini krisis sumber daya hayati semakin parah, di mana hutanhutan rawa dan terumbu karang di Pulau Bangka telah mengalami kerusakkan yang sangat parah. Di samping itu, sumber air tawar semakin berkurang, bentang alam Pulau Bangka semakin tidak beraturan, pembudidaya ikan di kolam dan tambak mengalami kerugian, dan menurunannya populasi ikan secara drastis. Menurut data yang dikeluarkan Pemerintah
Daerah baru-baru ini, lebih dari $60 \%$ hutan rawa telah tercemar akibat penambangan timah sejak 5 tahun terakhir ini. Sedangkan menurut masyarakat sejak dimulainya penambangan timah inkonvensional tahun 2000 berbagai jenis ikan sudah mulai sulit ditemukan seperti Ikan belida (Chitala spp.) dan udang galah (Macrobrachium rosenbergii).

Faktor lain yang secara tidak langsung mendorong terjadinya kerusakkan perairan umum adalah masalah ekonomi dan harga timah yang sangat mahal, sehingga merangsang masyarakat untuk melakukan penambangan. Harga $1 \mathrm{~kg}$ timah dapat mencapai Rp.150.000, dan dalam 1 hari setiap penambang timah dapat memperoleh lebih dari $8 \mathrm{~kg}$. Hal ini yang menarik minat masyarakat dan penanam modal dari luar negeri untuk membuka usaha penambangan timbah. Sejak Pemerintah Daerah membiarkan timah inkonvensioanl ini, Pulau Bangka menjadi daya tarik tersendiri bagi pencari kerja dari luar daerah.

Fenomena tentang penurunan kualitas perairan (pencemaran) yang terjadi di Pulau Bangka, menunjukkan permasalahan yang kompleks dan sulit dipahami jika hanya menggunakan satu disiplin keilmuan. Konsep sistem yang berlandaskan pada unit keragaman dan selalu mencari keterpaduan antar komponen melalui pemahaman secara holistik (menyeluruh) dan utuh, merupakan suatu alternatif pendekatan baru dalam memahami dunia nyata. Pendekatan sistem merupakan cara penyelesaian persoalan yang dimulai dengan dilakukannya identifikasi terhadap sejumlah kebutuhan, sehingga dapat menghasilkan suatu operasi sistem yang efektif. 
Oleh karena itu, kajian tentang pencemaran yang terjadi di perairan Pulau Bangka dapat dilakukan dengan pendekatan sistem dalam membangun model pengendalian pencemarannya dalam upaya mewujudkan perairan umum yang bersih dan lestari, sehingga pemanfaatan fungsinya dapat berkesinambungan.

Permasalahan penambangan timah inkonvensional di Pulau Bangka saat ini merupakan fenomena gunung es yang suatu saat dapat meledak dan menjadi masalah sosial yang berujung konflik dengan masyarakat lainnya. Untuk itu, upaya pengelolaan terhadap perairan umum di Pulau Bangka sudah sangat mendesak. Menyikapi hal ini diperlukan koordinasi antara Pemerintah Daerah dengan masyarakat dalam upaya menghentikan dan merehabilitasi ekosistem perairan. Keterlibatan masyarakat sangat diperlukan, karena penambangan timah inkonvensional yang berkembang sebagian besar dilakukan oleh masyarakat awam. Pemerintah sebagai pengambil keputusan mensinergikan berbagai komponen lainnya seperti swasta, perguruan tinggi, dan LSM untuk menyelesaikan permasalahan ini. Sehingga permasalahan penambangan timah inkonvensional ini dapat memiliki solusi yang baik. Penambangan timah yang dilakukan oleh masyarakat sebaiknya tidak dilarang, tetapi memenuhi persyaratan perundang-undangan tentang pertambangan yang berlaku. Sebatas kegiatan ini bernilai guna dan berhasil guna untuk kepentingan masyarakat dan negara serta tidak merusak lingkungan sebaiknya pemerintah tetap mendukung.

Pendekatan yang diterapkan didalam upaya pengelolaan tambang timah di Pulau Bangka mengandung unsur-unsur akomodatif, suportif, protektif, dan antisipatif. Akomodatif berarti bahwa pengelolaan kawasan mampu mengakomodasi kepentingan masyarakat luas tanpa merugikan pihak lain. Suportif berarti mampu mendorong pembangunan dan menjaga kelestarian sumber daya alam terutama ekosistem perairan. Protektif berarti mampu melindungi sumber daya yang secara ekologis sangat penting dan aspek-aspek lingkungan fisik lainnya. Antisipatif berarti mampu mengatasi konflik dalam pemanfaatan ruang.

\section{KESIMPULAN}

1. Penambangan timah ilegal di Pulau Bangka memiliki dampak yang besar terhadap kelestarian sumber daya perairan di Pulau Bangka. Dampak yang dihasilkan dari aktivtas tersebut di antaranya 1) sedimentasi dan perubahan bentang alam;2) meningkatnya kesuburan perairan dan kekeruhan; dan 3) kerusakkan ekosistem dan hilangnya biota perairan serta pencemaran logam berat.

2. Dampak besar dari aktivitas penambangan timah inkonvensional ilegal ini dalam jangka waktu panjang yaitu pencemaran logam berat jenis $\mathrm{Pb}$ (timah hitam).

3. Perlu upaya penanggulangan dan pengelolaan sumber daya perairan umum Pulau Bangka secara berkelanjutan dengan melibatkan stakeholders secara menyeluruh.

\section{PERSANTUNAN}

Kegiatan dari hasil riset kajian keanekaragaman hayati perairan bersifat asam di Pulau Kalimantan, Pulau Bangka, dan Pulau Sumatera, T. A. 2005 di Balai Riset Perikanan Perairan Umum, MarianaPalembang.

\section{DAFTAR PUSTAKA}

Badan Penelitian dan Pengembangan Pertanian. 1996. Survei Perikanan dan Sosial ekonomi di MCMA Selat Bangka, Sumatera Selatan.

http://wapedia.mobi/id/Suku_Bangka. 2007. Pulau Bangka.

Lasut, M. T. 2001. Penurunan kualitas lingkungan akibat aktivitas tambang. Suatu Pertimbangan Penting dalam Menentukan Kebijakan Sektor Pertambangan.

PPLH IPB dan Bapedalda Kabupaten Bangka. 2002. Proyek Pendataan dan Pemetaan Potensi Kondisi Lingkungan Hidup Tersebar di Kabupaten Bangka. Institur Pertanian Bogor.

Palar, H. 2004. Pencemaran dan Toksikologi Logam Berat. Penerbit PT. Rineka Cipta. Jakarta.

PT. Tambang Timah. 2000. Identifikasi Kolong Pasca Penambangan Timah di Wilayah Bangka-Belitung. Laporan Akhir.

Siagian, M., Hs. Saberina, \& H. Asmika. 1996. Penuntun Praktikum Ekologi Perairan. Fakultas Perikanan dan IImu Kelautan Universitas Riau. Pekanbaru. 109 pp.

Wargasasmita, S. 2002. Ikan air tawar endemik sumatera yang terancam punah. Jurnal Ikhtiologi Indonesia. Jakarta. 